NOTAS 



\title{
SIGNIFICADO Y ALCANCE DE LA INVIOLABILIDAD DEL REY
}

\author{
PATRICIA GARCÍA MAJADO \\ Investigadora postdoctoral \\ Universidad de Oviedo
}

TRC, n. ${ }^{\circ} 47,2021$, pp. 357-381

ISSN 1139-5583

\section{SUMARIO}

I. Inviolabilidad regia y soberanía. II. Funcionalidad de la inviolabilidad regia en la Monarquía parlamentaria española. III. El alcance temporal de la prerrogativa. IV. El alcance material: ¿también la crítica parlamentaria?

\section{INVIOLABILIDAD REGIA Y SOBERANÍA}

La Monarquía ha estado vinculada, desde sus orígenes, al instituto de la inviolabilidad. Se ha dicho, en efecto, que configura, junto con el carácter hereditario de la misma, el estatuto jurídico fundamental de la institución ${ }^{1}$. Aquélla, no obstante, ha mostrado una excelsa habilidad para perdurar en el tiempo y pervivir en sistemas muy diversos y en coordenadas jurídico-políticas muy dispares. Sus atributos característicos, aunque siempre hayan acompañado a la Monarquía, no siempre han ostentado el mismo sentido. Su propio fundamento y significado cambian en la medida en que los sistemas en los que aquélla se inserta también lo hacen. De ahí, precisamente, que la inviolabilidad no sea un instituto susceptible de ser precomprendido sino que deba ser necesariamente analizado en el marco de un orden normativo determinado. No en vano Jellinek sostenía que «lo

1 Aragón Reyes, M., Dos estudios sobre la Monarquía parlamentaria en la Constitución española, Madrid: Cuadernos Civitas, 1990, p. 100. No obstante, como sostenía Kelsen, H., Teoría General del Estado, trad. J. L. Moreneo Pérez, Granada: Comares, 2002, p. 542 más que el carácter hereditario, lo definitorio de la Monarquía es la posibilidad de que el Monarca designe libremente a su sucesor. 
individual solo puede comprenderse si se coloca dentro del encadenamiento general que le sirve de fundamento» ${ }^{2}$.

No es extraño encontrar en concepciones teocráticas de la Corona el fundamento clásico de la inviolabilidad del Rey. Del origen divino y, por tanto, metapositivo de la Monarquía se desprende la permanente infalibilidad de los actos de aquél. En todo caso, si tuviera que ser juzgado, no podría serlo por los poderes que de él emanan sino únicamente por quién ha sido su fuente última de existencia (metajurídica) ${ }^{3}$. Sin embargo, y dejando al margen estas tesis, en términos estrictamente jurídicos, el fundamento clásico de la inviolabilidad regia se explica de forma más coherente desde la naturaleza heterorreferencial ${ }^{4}$ de los sistemas absolutistas donde inicialmente se insertó la Monarquía, que le imputan a su titular —el Rey— la condición indiscutible de soberano.

Aquéllos son tales porque colocan fuera de las fronteras estrictamente normativas, y no dentro de las mismas, su fundamento último de validez; en este caso en un sujeto político: el Monarca absoluto. Éste es, en cuanto tal, un poder prejurídico y metapositivo ${ }^{5}$, de forma que no le debe al Derecho ni su propia existencia ni tampoco tiene porqué someter a él, que es su propio producto, su actuación. El Monarca es, en suma, el soberano. La inviolabilidad regia es consecuencia natural de la existencia de un legibus solutus, es decir, de un poder inmune que existe y se desenvuelve, en cuanto tal, fuera del terreno jurídico. De ahí que todos sus actos también resulten blindados frente a un orden normativo que no es autónomo sino que, hallando su propio origen en dicho sujeto, se encuentra necesaria y perpetuamente subordinado a aquél (heterorreferencialidad). La inviolabilidad es, así pues, una «inmunidad del poder $»^{6}$ en toda la extensión de la palabra, generada justamente por la existencia de ese poder inmune (el Rey), que no es sino un sujeto genuinamente soberano 7 .

2 Jellinek, G., Teoría General del Estado, trad. F. de los Ríos, México: Fondo de Cultura Económica, 2000 , p. 60.

3 Derivando la inviolabilidad del Rey de su origen divino véase, entre otros, FernándEZ-FonTECHA Torres, M., Pérez de Armiñán y de la Serna, A., La monarquía y la Constitución, Madrid: Civitas, 1987, pp. 40-41.

4 Sobre la heterorreferencialidad como contrapunto a la autorreferencialidad, cualidad que permite la autogeneración interna de los sistemas, véase, entre la vastísima obra del autor, LuHMANN, N., Sociedad y sistema: la ambición de la teoría, Barcelona: Paidós, 1990; Essays on self-reference, New York: Columbia University Press, 1990.

5 La atribución de un poder originario y prejurídico a un sujeto lo estudió con gran profundidad KANTOROwicz, E.H., The king's two bodies. A study in medieval political theology, Princeton: Princeton University Press, 2016. Dicha atribución, como expresión genuina del principio monárquico, típico del primer constitucionalismo alemán, se puede leer más extensamente en HeuN, W., «El principio monárquico y el constitucionalismo alemán del siglo Xix», en Varela Suanzes-Carpegna, J. (Coord.), Modelos constitucionales en la bistoria comparada. Fundamentos. Cuadernos monográficos Teoría del Estado, Derecho Público e Historia Constitucional, vol.2, Oviedo: Junta General del Principado de Asturias, KRK, pp. 559 y ss.

6 En los clásicos términos de GarCía DE EnTERRía, E., «La lucha contra las inmunidades del poder en el Derecho Administrativo (poderes discrecionales, poderes de Gobierno, poderes normativos)», Revista de la Administración Pública, 1962, pp. 159 y ss.

7 En términos similares, derivando el sentido clásico de inviolabilidad de la noción de soberanía, OLIVER León, B., «La irresponsabilidad como elemento sustancial de la monarquía», en Torres del Moral, A. 
Ahora bien, cuando la cualidad de la soberanía se despersonaliza, dejando de atribuirse a sujetos (en este caso, Monarca o Monarca y Parlamento) para pasar a imputarse al propio sistema jurídico en cuanto tal ${ }^{8}$, presidido en último término por una Constitución que es Norma Suprema del ordenamiento, dejan inevitablemente de existir poderes previos, ajenos y superiores al Derecho positivo. El principio monárquico deja así paso a la Monarquía constitucional, entendida ésta como una institución no solo jurídicamente limitada sino jurídicamente creada9 ${ }^{9}$ Un poder, en suma, plenamente constituido. $\mathrm{Y}$ es un poder constituido que, en la medida en que supone un déficit del principio democrático, dado que el acceso a un cargo público se produce por consanguinidad (art. $58 \mathrm{CE}$ ) y no por sufragio (art. $23 \mathrm{CE}$ ), ha sido deliberadamente desvestido, en el ordenamiento jurídico español, de potestades materiales, precisamente para que la institución pueda convivir de la forma más armónica posible con aquél. No obstante, el déficit se acentúa cuando aquélla está doblemente sometida para su cambio (ex Títulos I y Preliminar), al procedimiento agravado de reforma constitucional (art. $168 \mathrm{CE}$ ) pues la rigidez constitucional tiene por fin blindar los elementos esenciales del principio democrático ${ }^{10}$, no los ajenos al mismo y, según se ha visto, la Corona no lo es ${ }^{11}$.

Ahora bien, en estas nuevas coordenadas jurídicas, la inviolabilidad sigue acompañando a la institución monárquica. No en vano el art. $56.3 \mathrm{CE}$ establece, de forma similar a las precedentes Constituciones decimonónicas ${ }^{12}$, que «la persona

(Dir)., Monarquía y Constitución, Madrid: Colex, 2001, pp. 344-348. También apuntan en este sentido las consideraciones de Porras Ramírez, J.M., Principio democrático y función regia en la Constitución normativa, Madrid: Tecnos, 1995, pp. 175-176.

8 Kelsen, H., Teoría general del Estado, Granada: Comares, 2002, p. 170. La soberanía como cualidad solamente atribuible a normas, pues quien quiera que sea el soberano lo será en función de una norma que lo consagre tal, fue puesta de manifiesto asimismo por Ross, A., Sobre el Derecho y la justicia, Buenos Aires: Editorial Universitaria de Buenos Aires, 1994, pp. 79-81.

9 De Oтto, I., «Sobre la Monarquía», en Obras Completas, Oviedo: CEPC, Universidad de Oviedo, 2010, p. 1521.

10 De Отto, I., Derecho Constitucional. Sistema de fuentes, Barcelona: Ariel, 2010, pp. 59-61.

11 Así, entre otros, Aláez Corral, B., «El procedimiento de reforma constitucional cuarenta años después», en Álvarez Álvarez, L.; Punset Blanco, R. (Coords.), Cuarenta años de Constitución normativa (1978-2018), Cizur Menor: Thomson-Reuters Aranzadi, 2018, p. 656; BAstida Freijedo, F., «La Corona y la República», en Álvarez Álvarez, L.; Punset Blanco, R. (Coords.), Cuarenta años de Constitución normativa (1978-2018), ob. cit., p. 364. Otros, como TAjAdura TejADA, J., «La reforma de la Constitución (arts. 166-169 CE)», en Freixes Sanjuán, T.; Gavara de Cara, J.C. (Coords.), Repensar la Constitución. Ideas para una reforma de la Constitución de 1978: reforma y comunicación dialógica, vol. I, Madrid: BOE, 2016, p. 270, consideran improcedente reservar todo el Título II al procedimiento del art. $168 \mathrm{CE}$, entendiendo que sería suficiente con que lo estuviese el art. 1.3 CE, es decir, la Jefatura del Estado en sí misma. Considerando coherente el blindaje constitucional de la Monarquía con el papel que ésta desempeña en el ordenamiento español, ArAGÓN REYEs, M., «Veinticinco años de monarquía parlamentaria», Revista Española de Derecho Constitucional, n. ${ }^{\circ}$ 24, 2004, p. 15. Más allá se sitúa Belda Pérez-Pedrero, E., «Los límites a la reforma constitucional ante propuestas más propias de una revolución», Teoría y Realidad Constitucional, n. ${ }^{\circ}$ 29, 2012, pp. 271-282 quien parece decantarse por considerar la Monarquía como un límite implícito a la reforma constitucional.

12 Todas las Cartas Magnas de la historia constitucional española que habían recogido la institución monárquica, consagraron también la inviolabilidad del Rey: la de 1812 (art. 168), 1837 (art. 44), 1845 (art. 42), 1869 (art. 67) y 1876 (art. 48). 
del Rey es inviolable y no está sujeta a responsabilidad»; precepto que, por cierto, no sufrió alteraciones durante el proceso constituyente pues así aparecía ya recogido en el Anteproyecto de Constitución (art. 48.3) ${ }^{13}$. Dicho instituto pervive, por tanto, en un sistema jurídico democrático en el que la Constitución es Norma Suprema del ordenamiento. La inviolabilidad ya no puede explicarse, entonces, desde el carácter heterorreferencial del sistema normativo; ya no puede ser, en suma, la inmunidad del poder que se derivaba de la existencia ese indomable poder inmune (el Monarca absoluto). El fundamento de aquélla debe desligarse así necesariamente de aquella concepción subjetiva de la soberanía en la que originariamente hallaba su sentido.

Esto no debe significar, no obstante —al menos a priori- que la inviolabilidad regia deba ser necesariamente concebida como un anacronismo ${ }^{14}$ o una anomalía dentro del sistema democrático contemporáneo. Significa, tan solo, que ya no puede ser explicada desde sus antiguos y primigenios postulados ${ }^{15}$ : su fundamento no puede ser ahora más que el ordenamiento jurídico positivo y su significado último solo puede hallarse, como veremos, en las funciones que desempeña al servicio del propio sistema en el que se inserta, no en beneficio de elementos o pretensiones ajenos a éste ${ }^{16}$. La excepción ${ }^{17}$ que la inviolabilidad del Rey constituye tanto del deber de sometimiento de los poderes públicos al ordenamiento jurídico (art. 9.1 CE) como del principio de igualdad (art. 14) solo puede hallar su justificación última en su funcionalidad, es decir, solo puede resultar tolerable en la medida en que coadyuve al correcto funcionamiento de la institución (la

13 BOCG, n. ${ }^{\circ} 44$, de 5 de enero de 1978.

14 Véase, por ejemplo, Serra Cristóbal, R., «Las responsabilidades de un Jefe de Estado», Revista de Estudios Políticos, n. ${ }^{\circ}$ 115, 2002, p. 171; PÉrez Royo, J., Curso de Derecho Constitucional, $12 .^{\circ}$ Ed., Madrid: Marcial Pons, 2010, p. 605.

15 Esto significa, en línea con lo sugerido por EsCAJEdo SAN-EPIFANIO, L., «La inviolabilidad regia en perspectiva comparada: revisión histórica e interpretaciones contemporáneas», Teoría y Realidad Constitucional, n. ${ }^{\circ} 46,2020$, pp. 411-412, que el hecho de que la inviolabilidad haya existido con anterioridad a la Constitución Española de 1978 no puede significar en modo alguno que deba ser interpretada o explicada desde parámetros preconstitucionales. Al mismo tiempo, que sobreviva en las coordenadas jurídicas actuales tampoco debe entenderse necesariamente como una incoherencia interna del sistema si la prerrogativa cumple una función a su servicio, como se explicará en las siguientes páginas.

16 Esta es la perspectiva de análisis que propone también Oliver LEón, B., «Inviolabilidad regia y Constitución normativa», en AA.VV., Estudios de Derecho Público. Homenaje a Juan José Ruiz Rico, Vol. I, Madrid: Tecnos, 1997, p. 232 y 236, aunque luego llegue a conclusiones distintas de las que en este trabajo se defienden. Esta perspectiva funcional obliga a no buscar el fundamento de la prerrogativa en otras consideraciones de índole material, como el hecho de que el Jefe del Estado sea «la fuente de poder» como propone, por ejemplo, Pérez Serrano, N., Tratado de Derecho Político, Madrid: Civitas, 1976, p. 715.

17 En los términos propuestos por Carlassare, L., «Articolo 90», en Branca, G. (Coord.), Commentario della Costituzione, tomo II, Bolonia: Zanichelli, 1983, pp. 149-150, la inviolabilidad regia debe ser tomada como una excepción y no, en sí misma, como la regla general pues en un Estado democrático de Derecho ésta solo puede ser la sumisión al ordenamiento jurídico (art. 9.1 CE). Igualmente en este sentido, entre nosotros, Oliver LEón, B., «Inviolabilidad regia y Constitución normativa», ob. cit., p. 236. Esto es precisamente lo que obligará, como se analizará más adelante, a que la misma se interprete en términos restrictivos. 
Monarquía) a la que sirve ${ }^{18}$. Solo en la medida en que esta funcionalidad sea imposible de hallarse - y solo entonces_ estaremos en presencia de una anomalía, esto es, de un privilegio inadmisible, pero no antes.

\section{FUNCIONALIDAD DE LA INVIOLABILIDAD REGIA EN LA MONARQUÍA PARLAMENTARIA ESPAÑOLA}

Antes de tratar de desentrañar la función que la inviolabilidad del Rey puede desempeñar en nuestro sistema constitucional es preciso conocer su propio significado. El Tribunal Constitucional ha declarado - aunque en términos poco afortunados, como explicaremos posteriormente- que la inviolabilidad regia es un «privilegio de naturaleza sustantiva» ${ }^{19}$. Aunque al hilo de las prerrogativas parlamentarias, aquél ha puesto igualmente de manifiesto que dicha garantía no solo implica la irresponsabilidad jurídica por los actos que cometa su titular, sino la imposibilidad de incoar cualquier clase de procedimiento judicial contra éste, constituyendo así un límite absoluto a la jurisdicción ${ }^{20}$. La inviolabilidad tiene ese doble cariz de ausencia de responsabilidad en todos los ámbitos ${ }^{21}$ y de no sujeción a procedimiento judicial alguno ${ }^{22}$. En

18 Este es, en esencia, el juicio de funcionalidad que debe hacerse de todas las prerrogativas en tanto que excepciones al Derecho común. Así, tempranamente, Punset Blanco, R., «Sobre la extensión del ámbito personal de las prerrogativas parlamentarias», Revista Española de Derecho Constitucional, vol.1, n. ${ }^{\circ} 3$, 1981, p. 107. Y así lo ha entendido el Tribunal Constitucional desde su STC 51/1985, de 10 de abril.

19 STC 98/2019, de 17 de julio (FJ 3. ${ }^{\circ}$ b)

20 SSTC 243/1988, de 19 de diciembre (FJ 3..$^{\circ}$ ); 9/1990, de 18 de enero (FJ 3. ${ }^{\circ}$ ); 30/1997, de 24 de febrero (FJ 5. ${ }^{\circ}$ ); 78/2016, de 25 de abril (FJ 3..$^{\circ}$ ), entre otras. Lógicamente, la inviolabilidad parlamentaria solo cubre los votos y opiniones de los parlamentarios expresados en el ejercicio de sus funciones, es decir, es parcial y no total como la del Rey (art. 56.3 CE). Sin embargo, su alcance no altera su propia naturaleza jurídica. De ahí que se consideren pertinentes las reflexiones sobre la prerrogativa parlamentaria.

21 Hay quien distingue entre inviolabilidad e irresponsabilidad, entendiendo que la primera protege al Rey como persona y la segunda, por el contrario, a la Jefatura del Estado. En este sentido, por ejemplo, Rizzo, G., La responsabilità regia e le deposizioni dei Rei inglesi, Milán: Giuffrè, 1939, p. 258; Crossa, E., La monarchia nel diritto pubblico italiano, Torino: Bocca, 1922, p. 20; De Esteban, J.; López Guerra, L., El régimen constitucional español, vol. 2, Labor Univesitaria, Barcelona, 1982, p. 18; Herrero y RodríGuez DE MiÑón, M., «Artículo 56», en Alzaga Villamil, O. (Dir.), Comentarios a la Constitución Española de 1978, tomo V, Madrid: Cortes Generales, 1997, p. 76. Otros entienden que la inviolabilidad opera en el terreno jurídico y la irresponsabilidad en el terreno político como, por ejemplo, Cazorla Pérez, J., Ruiz Rico, J.J., Bonachela Mesas, M., Derechos, instituciones y poderes en la Constitución de 1978, Granada: Monachil, 1983, pp. 230-231; OLIVER LEÓN, B., «Ficciones jurídicas y cultura constitucional. La irresponsabilidad e inviolabilidad regia en el ordenamiento constitucional español», en Balaguer Callejón, F., Derecho constitucional y cultura. Estudios en homenaje a Peter Häberle, Madrid: Tecnos, 2004, p. 286. Por su parte, Biglino Campos, P., «La inviolabilidad de la persona del Rey y el refrendo de sus actos», en AA.VV., La Monarquía parlamentaria, VII Jornadas de Derecho Parlamentario, Madrid: Congreso de los Diputados, 2001, p. 203 pone de manifiesto que hay autores que atribuyen a la inviolabilidad un significado más amplio que a la irresponsabilidad, entendiendo que la primera es una declaración política que pone en valor la alta dignidad del Monarca como Jefe del Estado.

22 Así lo apunta Fernández Fontecha-torres, M., «Artículo 56», en Cazorla Prieto, L.M. (Dir.), Comentarios a la Constitución Española de 1978, Cizur Menor: Thomson Reuters Aranzadi, 2018, 
efecto, el Rey está exonerado incluso del deber de comparecer como testigo (art. 411 LECrim $)^{23}$.

Ahora bien, lo determinante es que, a tenor del art. 56.3 CE, inviolable no es «el Rey», sino «la persona del Rey» ${ }^{24}$. Quiere esto decir que el Monarca no puede ser sometido a la jurisdicción por ninguno de sus actos, sean estos ejecutados en calidad institucional de Jefe del Estado o en calidad de mero ciudadano particular ${ }^{25}$. La prerrogativa es, por tanto, «subjetiva» ${ }^{26}$, está personificada. Y así lo está, también, en la inmensa mayoría de las monarquías de nuestro entorno ${ }^{27}$.

pp. 1678-1679. En esta misma línea, González-Trevijano, P., «Artículo 56», en Pérez Tremps, P., Saiz Arnaiz, A., Comentario a la Constitución Española. 40 aniversario 1978-2018. Libro-homenaje a Luis López Guerra, Tomo I, Valencia: Tirant, 2018, p. 989. Esto ha llevado a algunos autores, como por ejemplo OLIVER LEón, B., «Ficciones jurídicas y cultura constitucional. La irresponsabilidad e inviolabilidad regia en el ordenamiento constitucional español», ob. cit., p. 290 a declarar que la inviolabilidad regia es una estructura compuesta, en la medida en que está conformada, en palabras del autor, por una «inviolabilidad sustancial» (irresponsabilidad jurídica material) y por otra «formal» (imposibilidad de incoación de procedimiento, asimilable entonces a la inmunidad).

23 También la Reina, el Príncipe Heredero y los Regentes del Reino (art. 411 LECrim).

24 Lógicamente, la prerrogativa solo la ostenta el Monarca, no puede extenderse al resto de miembros de la Familia Real pues la Constitución la atribuye exclusivamente a la persona del Rey. Así lo ha puesto de relieve la STC 111/2019, de 2 de octubre (FJ 5. ${ }^{\circ}$. Tampoco resultaría justificado que así se hiciera dado que el que desempeña la función que es objeto de protección, como veremos, es únicamente aquél. No obstante, hay autores, como Torres del Moral, A., «Estatuto jurídico del Príncipe de Asturias», en Torres del Moral, A. (Dir)., Monarquía y Constitución, ob. cit., p. 244 o Santolalla LóPez, F., «La posición constitucional del Príncipe de Asturias», en AA.VV., La Monarquía parlamentaria, VII Jornadas de Derecho Parlamentario, ob. cit., pp. 108-109, que consideran que sería deseable extender la inviolabilidad a la Reina consorte y los hijos de ambos.

25 En esta línea se sitúa, igualmente, la gran mayoría de la doctrina. Véanse, entre otros, Herrero y Rodríguez de Miñón, M., «Artículo 56», ob. cit., p. 75 y ss.; Fernández-Fontecha Torres, M., Pérez de Armiñán y de la Serna, A., La monarquía y la Constitución, ob. cit., p. 271; García Canales, M., La monarquía parlamentaria española, Madrid: Tecnos, 1991, pp. 121 y ss.; FernándeZ-Miranda CAMPOAMOR, C., «La irresponsabilidad del Rey: El refrendo: evolución histórica y regulación actual», Revista de Derecho Político, n. ${ }^{\circ}$ 44, 1998, p. 231; Solozábal Echevarría, J.J., «Irresponsabilidad e inviolabilidad del Rey», en Aragón Reyes, M. (Coord.)., Temas básicos de Derecho Constitucional, Tomo II, Madrid: Civitas, 2001, pp. 39-44; Biglino Campos, P., «La inviolabilidad de la persona del Rey y el refrendo de sus actos», ob. cit., pp. 206-207; Aragón Reyes, M., «La Corona», en Estudios de Derecho Constitucional, 3. . Ed., Madrid: CEPC, 2013, p. 808; Rodríguez PiÑero y Bravo-Ferrer, M., «Artículo 56», en Casas BaAmonde, M.E., Rodríguez Piñero y Bravo-Ferrer, M. (Coords.), Comentarios a la Constitución Española. XXX Aniversario, Madrid: Fundación Wolters Kluwer, 2008. En sentido contrario, entendiendo que aquélla cubre solo los actos institucionales del Jefe del Estado, Oliver León, B., «Inviolabilidad regia y Constitución normativa», ob. cit., pp. 235-237; DíAz Revorio, F. J., «Los retos de la Monarquía parlamentaria en España: adaptarse a los tiempos sin renunciar a su sentido histórico-simbólico y a su esencia legitimadora constitucional», Parlamento y Constitución, n. ${ }^{\circ}$ 16, 2014, p. 165; EsCAJEDO SAN-EPIFANIO, L., «La inviolabilidad regia en perspectiva comparada: revisión histórica e interpretaciones contemporáneas», ob. cit., p. 429. Otros, como por ejemplo PoRTero García, L., "La responsabilidad del Jefe de Estado», Revista General de Derecho, n. ${ }^{\circ} 448-449,1982$, pp. 470 y ss., tratan también de limitar el alcance de la prerrogativa buscando algún procedimiento para hacer efectiva la responsabilidad del Monarca.

26 Rodríguez Piñero y Bravo-Ferrer, M., «Artículo 56», en Casas Baamonde, M.E., Rodríguez Piñero y Bravo-Ferrer, M. (Coords.)., Comentarios a la Constitución Española. XXX Aniversario, ob. cit., p. 1237.

27 Como se puede ver, por ejemplo, en la Constitución belga (art. 88), la danesa (art. 13), la noruega (art. 5) o la holandesa (art. 42.2). Parece, en efecto, que la única excepción que cabría hacer sería Suecia, cuyo Instrument of Government (cap.5, art. 8) no asigna la inviolabilidad a la persona del Rey sino al «Rey o a la 
En no pocas ocasiones ha querido verse en la ausencia de potestades materiales del Rey y, por tanto, en el instituto del refrendo, el fundamento último de su inviolabilidad $^{28}$. En el seno de un sistema democrático, resultaría intolerable no solo que un sujeto no elegido de forma democrática, sino por consanguinidad (art. $57 \mathrm{CE}$ ), ostentara poder decisorio, sino que resultara jurídicamente irresponsable ejerciendo potestades materiales. El principio democrático neutralizó la potestas regia, de forma que el Rey, si bien debía llevar a cabo ciertos actos, debían estar predeterminados y revestir naturaleza formal, convirtiéndose así, mayoritariamente, en «actos debidos» ${ }^{29}$. A salvo quedan la gestión de fondos y los nombramientos de la Casa Real (art. 65 CE) y la propuesta de candidato a la Presidencia del Gobierno (art. 99 CE) que la propia jurisprudencia constitucional ha considerado como excepciones a su posición de auctoritas ${ }^{30}$.

Dado que el Monarca, en virtud de su inviolabilidad, no puede asumir las consecuencias que pudieran derivarse de sus actos, el instituto de refrendo vendría así a hacer efectivo el binomio decisión-responsabilidad ${ }^{31}$ que debe regir en democracia y que se traduce jurídicamente en la proscripción de la arbitrariedad de los poderes públicos (art. 9.3 CE). Aquél es absolutamente necesario para que los actos regios revistan validez jurídica (art. 56.3 CE y art. 64.1) —excepto para el nombramiento y relevo de miembros civiles y militares de la Casa Real (art. 65.2 CE) — operando así como un acto traslativo de responsabilidad del Monarca al órgano refrendante ${ }^{32}$ —Presidente del Gobierno, Ministros o Presidente del Congreso (art. 64.1 CE) ${ }^{33}$ - . El aforismo británico «the King cannot act alone» cobra entonces todo su sentido.

Reina que sea Jefe del Estado» y, a diferencia del caso español, también a la regencia correspondiente. Para un análisis de diversas Monarquías europeas véase Freixes SANJuÁn, T., «La Jefatura del Estado monárquica», Revista de Estudios Políticos, n. ${ }^{\circ} 73,1991$, pp. 83 y ss.

28 En este sentido, entre otros, considerando que la inviolabilidad viene determinada por el refrendo, FERnández-Fontecha Torres, M., «Artículo 56», en Cazorla Prieto, L.M.; Palomar olmeda, A. (Coord.), Comentarios a la Constitución Española de 1978, tomo I, ob. cit., p. 1677; BELdA-PÉrEZ PEDrERo, E., «Funciones del Rey y refrendo: el sometimiento pleno a la Constitución de la Monarquía del Siglo XXI», en PENDÁs, B. (Dir.), España constitucional (1978-2018). Trayectoria y perspectivas, Vol. IV, Madrid: CEPC, 2018, pp. 2986-2987

29 Así se ha pronunciado el Alto Tribunal en sus SSTC 5/1987, de 27 de enero; 8/1987, de 29 de enero.

30 STC 98/2019, de 17 de julio (FJ 3. ${ }^{\circ}$ a)

31 Reclamando la exigencia de responsabilidad allí donde existe poder, Duguit, L., Traité de Droit Constitutionnel, vol. II, Paris: Fontemoign/Boccard, 1928, p. 832.

32 Más extensamente sobre el refrendo, consúltense los trabajos de García CanALEs, M., «El refrendo en las Monarquías», Revista de Estudios Políticos, n. ${ }^{\circ}$ 212, 1977, pp. 325 y ss.; FERnÁndez-Miranda CAMPOAMOR, C., «La irresponsabilidad del Rey: El refrendo: evolución histórica y regulación actual», ob. cit., pp. 225 y ss.; González-Trevijano SÁnchez, P. J., El refrendo, Madrid: CEPC, 1998; López Guerra, L. M., «Las funciones del Rey y la institución del refrendo», en Torres del Moral, A. (Dir.), Monarquía y Constitución, ob. cit., pp. 389 y ss.; Porras Ramírez, J. M., «El principio de irresponsabilidad regia y el instituto del refrendo: apuntes para un estudio en claves histórica y jurídico positiva», en TORReS Del Moral, I., Monarquía y Constitución, ob. cit., pp. 373 y ss.; Torres Muro, I., «Refrendo y Monarquía», Revista Española de Derecho Constitucional, n. ${ }^{\circ} 87,2009$, pp. 43 y ss.

33 El Tribunal Constitucional, en buena lógica matizó en su STC 5/1987, de 27 de enero (FJ 2. ${ }^{\circ}$ ) que «la lectura del art. 64.1. CE debe realizarse entendiendo que son sujetos legitimados para efectuar el refrendo 
La existencia de refrendo fue lo que permitió que España ratificase, sin previa reforma constitucional, el Estatuto de Roma para la Corte Penal Internacional, de 17 de julio de 1998, que trataba de limitar la inviolabilidad de los Jefes de Estado en el ámbito internacional por delitos contra la humanidad. El Consejo de Estado, en su Dictamen 1374/1999, de 22 de julio ${ }^{34}$, consideró que no existía contradicción entre la Constitución y el Estatuto dado que no existía un vacío de responsabilidad por los actos del Rey, pues ésta existe, aunque trasladada al órgano refrendante, quien asume la «responsabilidad penal individual» del art. 25 de dicho Estatuto. La irresponsabilidad del art. 56.3 CE — considerójuega tan sólo en el ámbito interno pero no en el internacional ${ }^{35}$.

La tesis, a este respecto, es clara: dado que los actos del Rey son refrendados, el Monarca es inviolable porque nunca asume responsabilidad por los mismos. Sin embargo, esta argumentación no permite explicar, en su totalidad, el alcance de la inviolabilidad del Jefe del Estado. Y es que mientras el refrendo comprende los actos institucionales del Rey — salvo los que tienen que ver con el nombramiento y el relevo de los miembros civiles y militares de su casa (art. 65.2 CE) es decir, aquéllos que lleva a cabo en calidad de Jefe del Estado y en cumplimiento de las funciones que le atribuyen la Constitución y el resto del ordenamiento jurídico, la inviolabilidad cubre todos los actos de éste, también los de naturaleza estrictamente privada y, por ende, desprovistos de refrendo. En estos casos, no obstante, de su comisión responde administrativamente la Administración General del Estado, más concretamente la Casa del Rey ${ }^{36}$, que recibe una asignación de los Presupuestos Generales del Estado (art. 65 CE).

Si se entiende, por tanto, que el refrendo es el fundamento de la inviolabilidad regia, habría que colegir necesariamente que el Monarca es responsable de todo aquello que no ha sido refrendado, asimetría que no se compadece en absoluto con el aserto de que «la persona del Rey es inviolable» (art. 56.3 CE). La exención de responsabilidad jurídica atañe, pues, a todo lo que haga, sea en calidad o no de Jefe del Estado pues quien es inviolable no es $e l$ Rey — que es donde entra en juego el refrendo- sino la persona del Rey. Precisamente por ello, el

tanto el Presidente como los Ministros siempre y cuando el acto que refrendan entre dentro de su ámbito o esfera competencial de acuerdo con las funciones que la Constitución les atribuye».

34 Disponible aquí: https://boe.es/buscar/doc.php?id=CE-D-1999-1374 (consultado el 15/12/2020).

35 Sobre esta cuestión véase Rueda FERNÁndEZ, C., «El proceso de ratificación del estatuto de la corte penal internacional en el ordenamiento jurídico español», Boletín A ranzadi Penal, 2001; Biglino CAMPos, P., «La inviolabilidad de la persona del Rey y el refrendo de sus actos», ob. cit., pp. 206-213.

36 La STC 112/1984, de 28 de noviembre, admitió que el estatuto jurídico del personal de la Casa Real y los actos que en aplicación de esa regulación procedan de los órganos a los que se encomienda la gestión pueden ser sometidos a control jurisdiccional (contencioso-administrativo) y, en el caso de que se acuse la violación de un derecho fundamental, a través del recurso de amparo. Sobre el control jurisdiccional de la Casa del Rey, véase extensamente VACAs García-Alós, L., La Administración de la Casa del Rey su control jurisdiccional en el Derecho Constitucional español, Madrid: CEPC, 2002; GonzÁlez PÉREZ, J., «El control jurisdiccional de los actos del Jefe del Estado», en Martín-Retortillo Baquer, S. (Coord.), Estudios sobre la Constitución espanola: bomenaje al profesor Eduardo García de Enterría, Navarra: Civitas, 1991, pp. 1989 y ss. 
Monarca no es inviolable porque sus actos estén refrendados, sino que sus actos están refrendados porque el Rey es inviolable ${ }^{37}$. La fundamentación de la prerrogativa debe ser, por tanto, otra.

La vinculación de la inviolabilidad a la persona y no al cargo, en los términos previamente expuestos, es precisamente lo que ha generado más recelos hacia aquélla. Y ello porque, en cuanto sustracciones al Derecho común, las prerrogativas - para ser tales - deben estar conectadas a una función ${ }^{38}$, a cuyo correcto desarrollo precisamente han de servir. Por el contrario, pierden su justificación cuando se colocan al servicio de un sujeto, transmutándose entonces en privilegios. El Tribunal Constitucional parece, en efecto, que vacila entre ambas posiciones: si bien en un primer momento manifestó que la inviolabilidad del Rey «es un privilegio de naturaleza sustantiva», «relacionado con la persona y no con las funciones que el titular de la Corona ostenta» ${ }^{39}$, meses más tarde puso de relieve que las garantías del art. 56.3 CE atribuidas al Rey «le garantizan una defensa eficaz frente a cualquier tipo de injerencia de los otros poderes del Estado, por los actos que aquel realice en el ejercicio de sus funciones constitucionales» ${ }^{40}$. Sin embargo, este último aserto, a su vez, resulta contradictorio con el alcance general otorgado a la inviolabilidad por la propia jurisprudencia constitucional ${ }^{41}$, que ampara todos los actos llevados a cabo por el Monarca, tanto públicos como privados y, por tanto, también aquellos ajenos al desempeño de las funciones propiamente institucionales.

¿Estamos, entonces, ante una prerrogativa o ante un privilegio? Aunque en una primera aproximación pudiera pensarse que la inviolabilidad regia se alinea más con lo segundo, al colocarse al servicio del sujeto («la persona del Rey es inviolable») y no de la función, la síntesis que en una Monarquía se produce entre función-sujeto es tan intensa que sí es posible entenderla como una prerrogativa al servicio del sistema en el que se inserta. En otras palabras: que la inviolabilidad esté atribuida a la persona del Rey no impide, en último término, apreciar su funcionalización.

37 En efecto, el Tribunal Constitucional ha sostenido que «tal circunstancia de ausencia de responsabilidad es la que justifica la existencia del refrendo, que traslada la responsabilidad a las autoridades que refrenden aquéllos» (STC 98/2019, de 17 de julio, FJ 3. ${ }^{\circ} \mathrm{C}$ ). En sede doctrinal defienden la inviolabilidad como fundamento del refrendo y no a la inversa, entre otros, Biglino Campos, P., «La inviolabilidad de la persona del Rey y el refrendo de sus actos», ob. cit., p. 2016; RodríGuez Piñero y Bravo-Ferrer, M., «Artículo 56», ob. cit., p. 1239; Aragón Reyes, M., «La Corona», ob. cit., p. 808. Bastida Freijedo, F., «La Corona y la República», en Punset Blanco, R.; Álvarez Álvarez, L., Cuatro décadas de una Constitución normativa (1978-2018), ob. cit., pp. 368-369.

38 SSTC 51/1985, de 10 de abril (FJ 6. $\left.{ }^{\circ}\right) ; 90 / 1985$, de 22 de julio (FJ 6. $\left.{ }^{\circ}\right) ; 243 / 1988$, de 19 de diciembre (FJ 3. ${ }^{\circ}$ ); 9/1990, de 18 de enero (FJ 3..$^{\circ}$ ); 22/1997, de 11 de febrero (FJ 5. ${ }^{\circ}$ ); 123/2001, de 4 de junio (FJ $\left.3 .^{\circ}\right) ; 124 / 2001$, de 4 de junio (FJ 3. ${ }^{\circ}$ ), entre otras.

39 STC 98/2019, de 17 de julio (FJ 3. ${ }^{\circ} \mathrm{C}$ )

40 STC $111 / 2019$, de 2 de octubre (FJ $5 .{ }^{\circ} \mathrm{C}$ )

$41 \mathrm{Al}$ margen de en las anteriores y recientes sentencias, el Alto Tribunal, aunque obiter dicta, ya había declarado que la inviolabilidad regia revestía «alcance general» (STC 133/2013, de 5 de junio, FJ 6..$^{\circ}$ ) 
Siendo el Rey, tal y como reza el art. 56.1 CE, «símbolo de la unidad y permanencia del Estado», se entiende que aquél es tal siempre y en toda circunstancia, no resultando posible disociar su persona particular del cargo público que ostenta y encarna; algo que, sin embargo, sí es posible con los Jefes de Estado de las Repúblicas, lo que explica que, en éstas, la inviolabilidad se circunscriba exclusivamente a los actos institucionales de aquéllos ${ }^{42}$. Y es que, no es tanto que el Rey desempeñe una función simbólica sino que, en sí mismo, es símbolo de la unidad y permanencia del Estado (art. 56.1 CE) ${ }^{43}$. Por eso el Monarca no puede desvincularse de dicha condición, tampoco fuera de la esfera netamente institucional, pues ahí continúa siendo símbolo ${ }^{44}$. Lo es en toda circunstancia.

Así es posible explicar que proteger al sujeto, asignándole por entero la inviolabilidad a su persona sea, en último término, salvaguardar la función que desempeña, de ser símbolo, presente en toda su actuación, sea de la naturaleza que sea. Si sus actos no institucionales, de naturaleza privada, no resultaran cubiertos por la prerrogativa, la tarea que a aquél se le atribuye podría verse mermada pues no resulta fácil ser símbolo de la unidad y permanencia del Estado viéndose sometido a eventuales procesos judiciales que conllevarían, cada vez que dicha circunstancia aconteciese, la apertura del orden sucesorio ${ }^{45}$. El propio

42 Véase, por ejemplo, el art. 90 de la Constitución italiana, que dispone que «el Presidente de la República no será responsable de los actos realizados en ejercicio de sus funciones, salvo por alta traición o violación de la Constitución». A este respecto, la Corte Costituzionale, en su sentenza 1/2013 viene a subrayar de nuevo que los actos extrafuncionales del Presidente de la República no están sujetos cubiertos por la prerrogativa de la inviolabilidad. En esta misma línea se sitúan la Constitución francesa (art. 67), la griega (art. 49), la portuguesa (art. 130), etc.

43 Así, Torres del Moral, A., «Variaciones sobre la Monarquía como forma política», en Pendás, B. (Dir.)., España constitucional (1978-2018). Trayectorias y perspectivas, vol. IV, ob. cit., p. 2923. De esta cuestión se ha ocupado extensamente Rollnert Liern, G., La Jefatura del Estado. Símbolo e integración política en la Constitución vigente Valencia: Ed. Minim, 2002, quien puntualiza que aunque el Rey sea en todo caso símbolo de la unidad y permanencia del Estado no debe descartarse que, a su vez, desarrolla una función simbólica, de forma que el simbolismo atañe al ser y al hacer (pp.233-234).

44 En este sentido, Torres del Moral, A., Principios de Derecho constitucional español, 4. ${ }^{a}$ Ed., Madrid: Servicio de publicaciones Facultad de Derecho, Universidad Complutense de Madrid, 1998, p. 519 subraya que «el Rey es Rey veinticuatro horas diarias y trescientos sesenta y cinco días del año». En esta misma línea, Bastida Freijedo, F., «La Corona y la República», ob. cit., pp. 369; Herrero y Rodríguez de MiÑón, M., «Artículo 64», en Alzaga Villamil, O. (Dir.), Comentarios a la Constitución española de 1978, ob. cit., p. 294. A una conclusión diferente se llega cuando se entiende que el Rey no ostenta siempre la condición de tal al considerar que más que símbolo, desempeña una función simbólica que solamente está en juego cuando ejerce, propiamente, tareas institucionales y, en ese sentido, públicas. Tal postura conduce a vincular la inviolabilidad a los actos llevados a cabo en ejercicio de éstas. En este sentido, por ejemplo, Oliver León, B., «Inviolabilidad regia y Constitución normativa», ob. cit., pp. 228 y ss.

45 Esta interpretación es la que mantienen, entre otros, Biglino CAMPos, P., «La inviolabilidad de la persona del Rey y el refrendo de sus actos», ob. cit., pp. 206 y ss.; Bastida Freijedo, F., «La Corona y la República», ob. cit., pp. 369; García Canales, M., La monarquía parlamentaria española, ob. cit., pp. 121124. En esta misma línea, Delpérée, F., «La responsabilité du chef de l’État. Brèves observations comparatives», Revue Française de Droit Constitutionnel, n. ${ }^{\circ} 49$, 2002, p. 34 pone de manifiesto que la inviolabilidad del Rey «proscribe todas las medidas que comprometan el ejercicio continuo de su función» que es continua y permanente o, como el propio autor sostiene «no conoce de eclipses». 
Tribunal Constitucional ha subrayado, a este respecto, que las garantías que el art. 56.3 CE atribuye al Rey «se justifican en cuanto condición de funcionamiento eficaz y libre de la institución que ostenta» ${ }^{46}$.

Si la Monarquía existe y tiene encomendada tal función es lógico que el sistema constitucional, en su coherencia, prevea esta prerrogativa para que aquélla no se vea truncada. Por eso la inviolabilidad no es una rémora de otro tiempo, sino una garantía consustancial al régimen monárquico ${ }^{47}$. Lo que sucede es que, mientras otrora era un elemento heterorreferencial — colocado al servicio de cuestiones ajenas al sistema normativo (Monarca absoluto) - ahora es un elemento autorreferencial, que debe ser aprehendido desde la función que desempeña al servicio del funcionamiento del propio orden jurídico que lo crea y regula.

Los recelos que pudieran generarse frente al carácter omnicomprensivo de la prerrogativa que ahora nos ocupa no son sino recelos hacia la propia institución monárquica. Si en algún momento resulta difícil de tolerar la existencia de esta inviolabilidad absoluta, ello es síntoma de que, en realidad, lo que comienza a resultarlo es la existencia de una función simbólica, concentrada en un sujeto con carácter vitalicio y hereditario, de unidad y permanencia del Estado. Lo que resulta difícil de reconciliar no es entonces la inviolabilidad con el sistema democrático, sino más bien la lógica monárquica — respecto a la cual la inviolabilidad es tan solo una consecuencia, un elemento consustancial a su propia naturalezacon la propia lógica de aquél. Las reticencias frente a la inviolabilidad no son sino reticencias frente a la propia Monarquía ${ }^{48}$. Una eventual reforma de la Constitución ${ }^{49}$ que pretendiera lisa y llanamente restringir el alcance de la inviolabilidad estaría errando en el tiro ${ }^{50}$. La disyuntiva no es inviolabilidad o responsabilidad

46 STC 98/2019, de 17 de julio (FJ 3. ${ }^{\circ} \mathrm{C}$ )

47 Solozábal Echevarría, J.J., «Irresponsabilidad e inviolabilidad del Rey», ob. cit., p. 39.

48 En este sentido, resultan evocadoras las palabras de TORRes del MorAL, A., «La monarquía parlamentaria como forma política del Estado español», en LuCas Verdú, P. (Dir.), La Corona y la Monarquía parlamentaria en la Constitución de 1978, Madrid: Universidad Complutense de Madrid, 1983, p. 68 cuando sostiene, al hilo de la inviolabilidad del Rey en un sistema democrático, que «la situación es injusta por desigual y discriminatoria, pero es porque la Monarquía es una forma política desigual y discriminatoria. Y esta afirmación no es la invectiva de un convencido republicano, sino la conclusión de un elemental análisis».

49 Digo reforma de la Constitución porque considero que no es posible limitar el alcance la prerrogativa a través de una ley. Por una parte, el tenor de la Constitución es claro («la persona del Rey es inviolable»). Por otra, el propio Tribunal Constitucional ya ha reconocido que la prerrogativa es absoluta, de forma que cubre todos los actos de aquél. En consecuencia, no parece viable salvar la constitucionalidad de una ley que tratase de acotar el alcance de la prerrogativa. En este sentido, en septiembre de 2020 fue presentada una Proposición de Ley relativa a los actos del Rey sujetos a inviolabilidad, por Más País-Equo Compromís, orientada a restringir el alcance de la prerrogativa, inadmitida posteriormente a trámite en términos absolutos. Asimismo, también fue presentada una Proposición no de Ley relativa a la eliminación de la inviolabilidad y otras figuras de «especial protección judicial» a miembros de la familia real, de 14 de julio de 2020 y otra Proposición no de Ley por la que se insta al Gobierno a presentar un informe sobre las medidas que tiene previsto impulsar con el fin de acotar el concepto de «inviolabilidad» del Jefe del Estado, vista la comunicación de la Casa de S.M. El Rey, de 15 de marzo de 2020, de 19 de marzo de 2020.

50 Así lo proponen, entre otros, Serra Cristóbal, R., «Las responsabilidades de un Jefe de Estado», ob. cit., pp. 171-173; Martín Pallín, J. A., «La inviolabilidad del Rey», Actualidad Jurídica Aranzadi, 
jurídica sino, simplemente, Monarquía o República, pues ello condiciona plenamente el régimen jurídico al que están sometidos los distintos Jefes del Estado.

\section{EL ALCANCE TEMPORAL DE LA PRERROGATIVA}

Hallada la función que la inviolabilidad regia desempeña en el sistema constitucional español, su naturaleza misma de prerrogativa y, por tanto, de exención al Derecho común, exigen necesariamente su interpretación restrictiva ${ }^{51}$. Y esa necesaria restricción se proyecta fundamentalmente sobre el alcance temporal de aquélla pues el estrictamente material (actos institucionales/actos privados), a la vista de la rotundidad con que se expresa el art. 56.3 CE no deja, como se ha visto, demasiado espacio a la interpretación: «la persona del Rey es inviolable». Lo que sucede es que el carácter vitalicio de la Monarquía ha ofrecido tradicionalmente poco margen de maniobra para interpretar el alcance temporal de la inviolabilidad, que tiende a extenderse durante toda la vida del Rey. De ahí que aquélla pueda perfectamente traducirse, debido a ese carácter vitalicio, en impunidad perpetua si el reinado concluye con el fallecimiento del Monarca: entonces habrá sido, desde su acceso al trono, siempre inviolable. Ahora bien, cuando son la inhabilitación, la renuncia o la abdicación (arts.57.5 y 59.1 CE) los motivos del abandono del trono - como lo fue la abdicación de Juan Carlos el 19 de junio de $2014^{52}$ - entonces sí hay más espacio para analizar el alcance temporal de la prerrogativa pues el otrora Monarca abandonaría su condición de tal y, con ello, las prerrogativas que le habían sido atribuidas, como veremos a continuación.

Cuando el art. 56.3 CE dispone que «la persona del Rey es inviolable», debe entenderse necesariamente que lo es mientras es Rey. Ello explica, entre otras cosas, que durante el reinado de Don Juan Carlos hubieran sido inadmitidas a trámite las más diversas acciones contra su persona ${ }^{53}$. El hecho de que la inviolabilidad solo

num.854, 2012; Belda-Pérez Pedrero, E., «La evaluación y el control de los actos del Rey como presupuesto para mejorar la racionalización democrática de la Corona», Revista Catalana de Dret Públic, núm. 51, 2015, pp. 160-161 y, del mismo autor, «Funciones del Rey y refrendo: el sometimiento pleno a la Constitución de la Monarquía del Siglo XXI», ob. cit., pp. 2990-2991. Asimismo, en la XIV Legislatura el Presidente del Gobierno anunció en varias ocasiones la pretensión de eliminar o, al menos, restringir la inviolabilidad del Rey pero no llegaron a presentarse proyectos de reforma constitucional al respecto.

51 Así lo ha puesto de manifiesto el Tribunal Constitucional, aunque al hilo de las prerrogativas parlamentarias, en sus SSTC 51/1985, de 10 de abril (FJ 5. ${ }^{\circ}$ ); 243/1988, de 19 de diciembre (FJ 3..$^{\circ}$ ); 9/1990, de 18 de enero (FJ 3..$\left.^{\circ}\right) ; 22 / 1997$, de 11 de febrero (FJ 8..$^{\circ}$ ), entre otras.

52 Ley Orgánica 3/2014, de 18 de junio, por la que se hace efectiva la abdicación de Su Majestad el Rey Don Juan Carlos I de Borbón. De la cuestión de la abdicación se han ocupado más extensamente, entre otros, Torres del Moral, A., «En torno a la abdicación de la Corona», Revista Española de Derecho Constitucional, n. ${ }^{\circ}$ 102, 2014, pp. 13 y ss.; DE LA PEÑA RodríGueZ, L., «Reflexiones sobre la abdicación», Asamblea: Revista parlamentaria de la Asamblea de Madrid, n. ${ }^{\circ} 37,2017$, pp. 151 y ss.

53 Desde las más conocidas demandas de paternidad (Autos del Juzgado de Primera Instancia n. ${ }^{\circ} 19$ de Madrid, 13/2012 y 12/2012, de 9 de octubre), de rectificación por las declaraciones del Monarca al hilo de su discurso de Navidad (ATS 5620/2006, de 28 de febrero), hasta denuncias presentadas por la comisión de 
cubra los actos de la persona del Rey mientras sea Rey significa, con efectos retroactivos, que aquélla no cubre los llevados a cabo antes de su reinado, pues entonces no era Rey. No obstante, la exigencia de responsabilidad por este tipo de actos no podrá llevarse a cabo mientras el Monarca esté ocupando la Jefatura del Estado, pues en ese momento es inviolable, que es, justamente, lo que sucedió con las demandas de paternidad, pues el nacimiento de los supuestos hijos era anterior al acceso al trono pero la reclamación de filiación se hizo durante el reinado ${ }^{54}$. Con efectos prospectivos, no cabe inviolabilidad ultra officium. Cuando el Monarca abdica, renuncia o se inhabilita para el cargo (art. 57.5 y 59.1 CE) deja de ser Rey, desapareciendo por consiguiente la especial protección que la prerrogativa le confiere dado que ya no desarrolla las funciones que justificaban la atribución de la inviolabilidad a su persona. Por tanto, aquél no resulta inviolable por los hechos llevados a cabo con posterioridad a su abdicación ${ }^{55}$. Y ello a pesar de que, en este caso, D. Juan Carlos siga conservando el título de Rey pues lo hace a efectos meramente honoríficos ${ }^{56}$.

Ahora bien ¿qué sucede con los llevados a cabo durante el reinado que no hubieran sido refrendados una vez que el Monarca abdica? ¿Continúan o no cubiertos por la inviolabilidad? Sobre este extremo pivota fundamentalmente el centro de la discusión, que dista de ser pacífica. En la Exposición de Motivos (IV) de la Ley Orgánica 4/2014, de 11 de julio, complementaria de la Ley de racionalización del sector público y otras medidas de reforma administrativa por la que se modifica la Ley Orgánica 6/1985, de 1 de julio, del Poder Judicial — que es la que introduce, como posteriormente se verá, el fuero jurisdiccional para los miembros de la Casa Real- dice expresamente que los actos realizados por el

delitos contra la Hacienda Pública (ATS 9060/2014, de 22 de octubre), de lesa humanidad (ATS 18221/2005, de 28 de noviembre) o por no haber sido el querellante, según expresa éste, recibido en audiencia por S.M. para poderle exponer los que denomina presuntos delitos cometidos por Tribunales Médicos Militares (ATS 1580/1992, de 17 de febrero), entre otras.

54 Sobre esta cuestión véase más extensamente GALERA ViCTORIA, A., «Las demandas de filiación y la Corona. Reflexiones sobre la inviolabilidad regia. El acceso a la jurisdicción y la igualdad entre los hijos», Revista de Derecho UNED, n. ${ }^{\circ} 17,2015$, pp. 319 y ss.

55 En sentido contrario al que aquí se sostiene, Aragón REYES, M., «La monarquía parlamentaria», en Pendás, B (Dir.), España constitucional (1978-2018). Trayectorias y perspectivas, vol. I, ob. cit., 2018, p. 648, entiende que, como la inviolabilidad se predica de «la persona del Rey», mientras exista tal persona, es decir, hasta su muerte, la prerrogativa acompaña a quien ostentó la Corona, aunque ahora ya no la ostente. Desde esta perspectiva, la inviolabilidad se configuraría como una prerrogativa prácticamente vitalicia desde el acceso al trono, algo que se compadece mal con su carácter funcional.

56 Téngase en cuenta que el Real Decreto 470/2014, de 13 de junio, por el que se modifica el Real Decreto 1368/1987, de 6 de noviembre, sobre régimen de títulos, tratamientos y honores de la Familia Real y de los Regentes previó que Don Juan Carlos y Doña Sofía continuaran vitaliciamente en el uso con carácter honorífico de los títulos de «Rey» y «Reina», respectivamente, con tratamiento de Majestad y honores análogos a los establecidos para el Heredero de la Corona, Príncipe o Princesa de Asturias o sus consortes en el Real Decreto 684/2010, de 20 de mayo, por el que se aprueba el Reglamento de Honores Militares. De la cuestión de los títulos honoríficos de la Familia Real se ocupó tempranamente LóPEZ VILAs, R., «Títulos, tratamientos y honores de la Familia Real. El Registro Civil de la Familia Real», en AA.VV., La Monarquía parlamentaria, VII Jornadas de Derecho Parlamentario, ob. cit., pp. 449 y ss. 
Rey durante el tiempo en que ostentare la jefatura del Estado «cualquiera que fuere su naturaleza, quedan amparados por la inviolabilidad y están exentos de responsabilidad», estando sometidos a control jurisdiccional, «los que realizare después de haber abdicado» y subrayando la necesidad de regular el régimen jurisdiccional que le sería aplicable «por hechos posteriores a su abdicación». En términos similares se expresa el informe del Consejo de Estado 1/2018, de 16 de noviembre, sobre la propuesta de reforma constitucional sobre modificación de los aforamientos, al sostener que, si bien el texto constitucional no prevé aforamiento alguno para el Monarca o ex Monarca, el art. 55 bis LOPJ sí lo contempla «para los actos realizados después de su abdicación»" ${ }^{57}$. De ambos textos - carentes, por otro lado, de valor normativo- parece deducirse que los actos del Rey llevados a cabo durante el reinado son eternamente inviolables, de manera que la fiscalización jurisdiccional es solo posible para los hechos acaecidos con posterioridad.

Es cierto que, tras la abdicación de D. Juan Carlos, en 2015, el Tribunal Supremo inadmitió varias demandas de paternidad, no en virtud de la inviolabilidad — como había sucedido previamente- sino por falta de un principio de prueba $^{58}$. Sin embargo, el hecho de que la inviolabilidad no haya entrado en juego en estos casos no es tanto porque el Tribunal haya entendido que ésta desaparece cuando deja de ostentarse la condición de Monarca, sino muy posiblemente porque los hechos de los que debía conocer en ese caso eran sensiblemente anteriores a su proclamación como Rey de España: el nacimiento de los sujetos que reclamaban el reconocimiento de la filiación era previo a 1978. Ahora bien, la Audiencia Nacional también archivó las piezas de la «Operación Tándem» que investigaba las grabaciones del comisario J.M. Villarejo a Corinna Larsen en 2015, en las que ésta aludía a actuaciones del Rey emérito que podrían ser delictivas, por entender que no existían indicios de comisión de delito y, además, y en todo caso, porque pertenecían a un periodo de tiempo en el que el Monarca estaba amparado por la prerrogativa de la inviolabilidad. Mucho más recientemente, la propia Fiscalía ha anunciado que pedirá al Tribunal Supremo que archive las diligencias abiertas contra D. Juan Carlos por presuntos delitos de blanqueo de capitales al corresponder los mismos al periodo de su reinado y estar entonces cubiertos por su inviolabilidad. No es descabellado aventurar que los Tribunales serán altamente reticentes a fiscalizar actuaciones del Rey emérito pertenecientes a la etapa del reinado, entendiendo que la prerrogativa blinda de forma perpetua los actos llevados a cabo durante tal periodo.

La cuestión dista de ser tanto pacífica como sencilla. Si la inviolabilidad solo consistiese en ese límite absoluto a la jurisdicción, esto es, en la imposibilidad

57 Disponible aquí: http://www.consejo-estado.es/pdf/Informe\%20Consejo\%20de\%20Estado.PDF (consultado el 15/12/2020).

58 AATS 152/2015, de 28 de enero (FJ 4..$^{\circ}$; 163/2015, de 4 de febrero (FJ 2..$^{\circ}$. 
jurídica de incoar procedimientos judiciales —asimilándose así a la inmunidad- parece mucho más claro que sí sería posible procesar al ex Jefe del Estado por los actos de su reinado que no hubieren sido refrendados: en el momento en que esa «barrera procesal» se levantase podrían revisarse dichas actuaciones ${ }^{59}$. En efecto, esto es lo que sucede con la inmunidad parlamentaria, que solo protege a diputados y senadores durante su mandato pero no posteriormente, pues el obstáculo a la procedibilidad en que la prerrogativa — de carácter formal ${ }^{60}$ — consiste desaparece con el cese en las funciones de aquéllos (art. 71.2 CE).

No obstante, si el constituyente hubiera querido que la prerrogativa regia consistiera solo en la imposibilidad de procesamiento, quizás hubiera previsto que la persona del Rey fuera inmune, no inviolable. Desde el momento en que la inviolabilidad no supone solo la prohibición de ser sometido a un proceso judicial, sino que «touche au fond» ${ }^{61}$, conllevando la irresponsabilidad jurídica de su titular —en este caso total — no resulta sencillo sostener que aquélla solo comporta el primero de los aspectos sin desnaturalizarla. Siendo esto así, podría quizás entenderse que, con el reconocimiento constitucional de la inviolabilidad regia, la pretensión era blindar jurídicamente en términos materiales la actuación del Monarca, no impedir tan solo (temporalmente) su procesamiento. Esta dualidad resulta irrelevante en términos prácticos durante el periodo del reinado — si no hay posibilidad de procesamiento tampoco la hay para exigir responsabilidades- pero deviene nuclear tras la abdicación pues, aun cuando ahí se levanta esa barrera procesal, cabría entender que la protección sustantiva de dichos actos proscribe la exigencia de responsabilidades a posteriori. Si no fuera así, sería sustancialmente lo mismo ser inmune que inviolable. El aserto de que la persona del Rey es inviolable significaría desde esta perspectiva que los actos llevados a cabo en calidad del Rey (durante el reinado) son siempre inviolables ${ }^{62}$.

59 En efecto, este es el planteamiento de, entre otros, Oliver LEón, B., «Ficciones jurídicas y cultura constitucional. La irresponsabilidad e inviolabilidad regia en el ordenamiento constitucional español», ob. cit., pp. 290-291, 295-296, quien considera que los actos del reinado no refrendados son perseguibles judicialmente una vez que el Monarca abandona el trono al entender que dichos actos que caen fuera de las funciones institucionales del Rey no están cubiertos por la inviolabilidad sustancial (irresponsabilidad jurídica) sino por la inviolabilidad formal (imposibilidad de procesamiento), que se levanta una vez aquél abdica o se inhabilita para el cargo. En términos muy similares, Rodríguez RAmos, L., «Inviolabilidad del Rey», en Cobo del Rosal, M. (Dir.), Comentarios a la legislación penal, Madrid: Revista de Derecho Privado, 1982, pp. 284-287, entiende que la inviolabilidad es solo un obstáculo procesal y que la irresponsabilidad solo atañe a los actos refrendados (ahí se torna en indemnidad), por los que todos aquellos no sometidos a refrendo son susceptibles de ser enjuiciados una vez que el Rey deja de ser tal, ya que desaparece la prohibición de incoar procedimientos judiciales que es en lo que para él consiste la inviolabilidad.

60 Así lo ha señalado el Tribunal Constitucional en sus SSTC 243/1988, de 19 de diciembre (FJ 3. ${ }^{\circ}$ ); 9/1990, de 18 de enero (FJ 3..$^{\circ}$ ); 206/1992, de 27 de noviembre (FJ 3. ${ }^{\circ}$ ), entre otras.

61 Barthélemy Duez, J., Traité de Droit Constitutionnel, París, 1933, p. 570.

62 Así, entre otros, DelperéE, F., «Immunités constitutionnelles et privilèges de jurisdiction», Annuaire international de justice constitutionnelle, 2001, p. 164. Por su parte, Gómez SÁnCHEZ, Y., «Sucesión a la Corona, abdicación y proclamación», PENDÁs, B (Dir.)., España constitucional (1978-2018). Trayectorias y perspectivas, vol. IV, ob. cit., p. 3011, considera que los actos del reinado no pueden ser jurisdiccionalmente 
No obstante, tampoco resulta descabellado sostener la tesis contraria y entender que la inviolabilidad no blinda ad eternum los actos pertenecientes al reinado que no hayan sido objeto de refrendo tras el abandono del trono. Y es que, el hecho de que la inviolabilidad sea una prerrogativa de carácter material no debe significar necesariamente que sea perpetua o, lo que es lo mismo, que produzca efectos jurídicos permanentes, máxime si debe interpretarse de manera restrictiva. Si bien aquélla reviste naturaleza sustantiva y es, además, absoluta, no «borra» los hechos llevados a cabo por su titular o su potencial antijuridicidad, sino que impide su conocimiento en sede judicial y libera a su titular de las consecuencias jurídicas de los mismos ${ }^{63}$. En otras palabras: no es que no exista responsabilidad jurídica, sino que no se exige porque se exonera de la misma a su titular. Lo relevante es que esa exoneración, si bien es total, no es perpetua pues solo opera durante un determinado periodo de tiempo: mientras el sujeto en cuestión es Rey. De lo contrario, sería, sencillamente, impunidad. Entonces, si los hechos del reinado «permanecen» a efectos del ordenamiento jurídico y, debido a la abdicación, renuncia o inhabilitación desaparece la garantía que (temporalmente) los blinda — procesal y materialmente - parece posible el procesamiento del ex Monarca a posteriori.

Frente a esto podría aducirse que la inviolabilidad parlamentaria protege a los diputados y senadores por las opiniones vertidas el ejercicio de sus funciones «aún después de haber cesado en su mandato» (art. 17 RC, art. $36 \mathrm{RS)}$ ). Sin embargo, no resulta correcto asimilar ambas prerrogativas, no solo porque tienen un ámbito material diferente sino, fundamentalmente, porque cumplen funciones distintas. El alcance temporal en el caso de la parlamentaria se justifica porque si aquéllos pudieran ser perseguidos por las expresiones manifestadas en el ejercicio de sus funciones cuando cesasen en las mismas, dicha posibilidad ejercería un efecto inhibidor

fiscalizados a posteriori pero no por las consideraciones realizadas en el texto sino en base al principio de irretroactividad de las disposiciones sancionadoras (art. 9.3 CE). No obstante, si la ley que se aplica al Monarca abdicado estaba en vigor cuando se cometieron los hechos presuntamente ilícitos, parece que no cabe hablar de irretroactividad. Cosa distinta, y entonces sí entraría en juego el art. 9.3 CE, es que se le aplicaran al ex Jefe del Estado normas que entraron en vigor con posterioridad a la abdicación.

63 Desde el punto de vista de la dogmática jurídico-penal, la inviolabilidad se configura para buena parte de la doctrina como una causa personal de exclusión de la pena. En este sentido, entre otros, RoDRíGUEz DEvESA, J.M., Derecho penal español. Parte general, Madrid: Dykinson, 1991, pp. 655-656; González CussaC, J., Cuerda Arnau, M.L., «Aproximación al Derecho Penal parlamentario: inviolabilidades», Cuadernos de Derecho Público, n. ${ }^{\circ} 1,1997$, pp. 113 y ss.; Cobo Del Rosal, M., Quintanar Díez, M., Instituciones de Derecho penal español. Parte general, Madrid: CESEJ, 2004, p. 106; Muñoz Conde, F., García Arán, M., Derecho Penal. Parte General, 8 a $^{a}$ Ed., Valencia: Tirant, 2010, p. 177; LuZón-PeÑA, D.M., Lecciones de derecho penal. Parte general, 3. ${ }^{a}$ Ed., Valencia: Tirant, 2010, pp. 379-380. No obstante, debe tenerse en cuenta que la responsabilidad de la que exonera la inviolabilidad no es solamente la penal, sino toda responsabilidad jurídica (civil, administrativa, etc.). La punibilidad no agota la responsabilidad a la que se refiere el art. 56.3 CE, como acertadamente señala FERNÁNDEZ-FONTECHA TORRES, M., «Artículo 56», ob. cit., p. 1677. Dentro de la doctrina constitucional, se posicionan también en este sentido, entre otros, Portero García, L., Inviolabilidad e inmunidad parlamentarias, Málaga: Universidad de Málaga, 1979, pp. 14 y ss.; Fernández-Viagas, BArtolomé, P., La inviolabilidad e inmunidad de los Diputados y Senadores. La crisis de los privilegios parlamentarios, Madrid: Cuadernos Civitas, 1990, pp. 24 y ss. 
en el uso de la palabra en la tribuna, frustrándose así el objetivo último de la inviolabilidad que es proteger la actividad de crítica y deliberación en sede parlamentaria, esencial para la libre formación de la voluntad del órgano ${ }^{64}$. Por eso el legislador estableció el blindaje posterior al abandono del cargo ${ }^{65}$.

En el caso de la prerrogativa regia, sin embargo, no existe razón funcional que aconseje blindar los actos pertenecientes al periodo del reinado tras la abdicación pues la posibilidad de ser judicialmente perseguido tras ésta no merma el ejercicio de las funciones atribuidas al Monarca mientras fuera tal y, por tanto, mientras las ejerció efectivamente ${ }^{66}$. Y, como de lo que se trata es de proteger el desempeño de la función, si ésta no resulta obstaculizada no hay razón para extender el alcance de la inviolabilidad previéndola ultra officium pues, como prerrogativa que es, debe interpretarse restrictivamente. Lo único que resultarían mermadas serían las pretensiones de delinquir — como le sucede a cualquier otro ciudadano- o, en todo caso, las de abdicar.

Desde esta perspectiva funcional, lo relevante es cuándo se le piden responsabilidades jurídicas al Rey (durante su reinado) y no tanto respecto a qué actos (los del reinado u otros). Lo que entorpece el desarrollo de las funciones regias - y, por tanto, justifica la prerrogativa - no es que se procese a D. Juan Carlos por bechos de su reinado incluso después de haber finalizado éste, sino que se procese a la persona del Rey mientras ocupa dicho cargo cualesquiera que sean aquéllos (incluso previos a aquél). Es en ese periodo cuando su función podría resultar mediatizada si pudiera procesársele. La entrada en juego de la jurisdicción habiéndose perdido la condición de Rey ya no supone un menoscabo para ser símbolo de la unidad y permanencia del Estado pues éste no está encarnado en la persona del ex Monarca, sino en la de su sucesor.

Sea como fuere, lo único que sucede es que los procedimientos judiciales que se abran contra el ex Monarca deben residenciarse ante el Tribunal Supremo. A raíz de su abdicación, la Ley Orgánica 4/2014, de 11 de julio, complementaria de la Ley de racionalización del sector público y otras medidas de reforma administrativa por la que se modifica la Ley Orgánica 6/1985, de 1 de julio, del Poder Judicial previó el aforamiento de «la Reina consorte o el consorte de la Reina, la Princesa o Príncipe de Asturias y su consorte, así como contra el Rey o Reina que hubiere abdicado y su consorte», contenido ahora en el art. 55 bis LOPJ ${ }^{67}$.

64 STC 51/1985, de 10 de abril.

65 Algo, por cierto, que no sería necesario prever expresamente si la inviolabilidad blindase perpetuamente tales expresiones, pues sería superflua la previsión.

66 En este sentido, Bastida Freijedo, F., «La Corona y la República», ob. cit., pp. 369-370.

67 No obstante, el aforamiento del Rey emérito apareció inicialmente contemplado en el Anteproyecto de Ley Orgánica del Poder Judicial (arts. 88-89) presentado por el Gobierno en abril de 2014 —disponible aquí: http://s01.s3c.es/imag/doc/2014-04-07/xx.Poderjudicial.pdf (consultado el 15/12/2020)_ e informado favorablemente, en lo que aquí interesa, por el Consejo General del Poder Judicial en junio de ese mismo año (http:// www.poderjudicial.es/cgpj/es/Poder_Judicial/Consejo_General_del_Poder_Judicial/ Actividad_del_CGPJ/ Informes/Informe_al_Anteproyecto_de_Ley_Organica_del_Poder_Judicial (consultado el 15/12/2020). 
La Exposición de Motivos de dicha ley pone de relieve la necesidad y conveniencia de su regulación «atendiendo a la dignidad de la figura de quien ha sido el Rey de España, así como al tratamiento dispensado a los titulares de otras magistraturas y poderes del Estado», concurriendo «similares razones» para aforar al resto de sujetos que contempla el antedicho precepto ${ }^{68}$. Sin embargo, el aforamiento no se establece por cuestiones de dignidad — de la que, por otra parte, gozan todos los ciudadanos-o relevancia, sino en atención a la autonomía e independencia de ciertos sujetos en cuanto titulares de determinados cargos públicos ${ }^{69}$. Mientras que la primera lógica es consustancial a un régimen de privilegios, la segunda es característico de un sistema de prerrogativas. Así pues, resultando muy cuestionable el fuero jurisdiccional en sí mismo considerado aun cuando se pone al servicio de determinadas funciones públicas, pues no parece que éstas resultaran lesionadas si los sujetos que las desempeñasen fueran juzgados por los jueces naturales $^{70}$, mucho más cuestionable resulta su extensión a sujetos que no ostentan cargo público alguno, como sucede con el Monarca abdicado ${ }^{71}$.

\section{EL ALCANCE MATERIAL: ¿TAMBIÉN LA CRÍTICA PARLAMENTARIA?}

Junto con la responsabilidad jurídica se ha entendido que el art. 56.3 CE exime también al Monarca de responsabilidades políticas. Y ello, tanto si se entiende que la inviolabilidad impide la exigencia de todo tipo de responsabilidades, tanto

68 En términos similares se expresó el CGPJ, en cuyo informe al Anteproyecto de Ley Orgánica del Poder Judicial de 2014 — citado en la nota precedente_- valoró positivamente esta elección «al tratarse de personas consideradas de la máxima relevancia para el Estado».

69 Véanse las SSTC 55/1990, de 28 de marzo (FJ 6. ${ }^{\circ}$ ), 166/1993, de 20 de mayo (FJ 3. ${ }^{\circ}$ ). 22/1997, de 11 de febrero (FJ 6..$^{\circ}$ ), 65/2001, de 17 de marzo (FJ 4..$^{\circ}$ ).

70 Un análisis crítico de esta institución puede encontrarse, entre otros, en MARTínez Elipe, L., «Prerrogativas parlamentarias», Teoría y Realidad Constitucional, n. ${ }^{\circ}$ 5, 2000, pp. 43 y ss.; MARTínez Alarcón, M. L., «El aforamiento de los cargos públicos: Derecho español y Derecho Comparado», Teoría y Realidad Constitucional, n. ${ }^{\circ}$ 35, 2015, pp. 437 y ss.; Gómez Colomer, J. L., «Privilegios procesales inconstitucionales e innecesarios en la España democrática del S.XXI: el sorprendente mantenimiento de la institución del aforamiento», Teoría y Realidad Constitucional, n. ${ }^{\circ}$ 38, 2016, pp. 239 y ss.; Presno LinerA, M.A., «Fatiga del parlamentarismo y algunas propuestas para revitalizarlo», en Pinelli, C.; Presno Linera, M.A., Crisis de la representación y nuevas vías de participación política, Madrid: Fundación Coloquio Jurídico Europeo, 2014, p. 115

71 En este sentido, criticando que el aforamiento se otorgue a quien no tiene tarea pública encomendada, aunque pareciendo admitir el especial trato procesal de favor si existiese una previsión constitucional BeldA, E., ¿Qué le falta a la Monarquía española para estar plenamente racionalizada?, Valladolid: Fundación Aranzadi Lex Nova, 2015, p. 81. En la misma línea, si bien poniendo de relieve los matices que atienden a la especial relevancia pública del sujeto en cuestión, los cuales podrían justificar en último término el aforamiento, Torres del Moral, A., «En torno a la abdicación de la Corona», Revista Española de Derecho Constitucional, n. ${ }^{\circ}$ 102, 2014, pp. 31-35. Considerando que el aforamiento del Monarca abdicado encaja en nuestro orden constitucional, Gómez SÁNCHEZ, Y., «Sucesión a la Corona, abdicación y proclamación», ob. cit., p. 3012. También parece aceptar su viabilidad RIDAO, J., «Abdicación y Monarquía parlamentaria en la España del S.XXI», Derecho y Cambio Social, n. ${ }^{\circ}$ 37, 2014, pp. 21-22. 
jurídicas como políticas, como si se considera — como lo hacen algunos autoresque mientras que la inviolabilidad exonera de las primeras, la irresponsabilidad lo hace de las segundas ${ }^{72}$.

La Constitución no prevé actualmente ningún mecanismo para destituir políticamente al Monarca. Por un lado, la abdicación y la renuncia (art. 57.5 CE), como tales, son actos voluntarios de éste y además definitivos. Por otro, la inhabilitación de aquél por las Cortes parece revestir naturaleza civil, estando pensada para aquellos supuestos en los que causas físicas o psíquicas inhabiliten al Monarca para el ejercicio de su autoridad (art. 59.2 CE) y, además, con carácter temporal, pues correlativamente se activa la regencia. Esta pudiera ser una vía para que el Parlamento pudiera cesar a un Rey — pero con carácter permanente, abriendo el orden sucesorio - que, debido a su comportamiento delictivo o la dejación de sus funciones como tal, resultase políticamente inhabilitado para seguir siendo el Jefe del Estado ${ }^{73}$. A partir de ahí, obviamente, perdería su status de Monarca con las prerrogativas que aquél comporta, pudiendo entonces ser juzgado a posteriori. Sin embargo, no parece que la redacción actual admita cómodamente la posibilidad de llevar a cabo esa inhabilitación política siendo tal vez necesaria, a estos efectos, una previa reforma constitucional que además precisara el carácter definitivo, y no temporal, de dicha inhabilitación, más acorde con la finalidad que aquélla pretende perseguir en este caso $^{74}$. Quizás sea aquí donde deban focalizarse los esfuerzos reformistas y no tanto en la inviolabilidad en sí misma considerada.

La cuestión de la responsabilidad política, que tradicionalmente ha pasado desapercibida, cobró importancia a raíz, en primer lugar, de una moción de reprobación a Felipe VI, adoptada por el Parlamento de Cataluña ${ }^{75}$. En ella se

72 Véase al respecto la nota 21.

73 En este sentido, entre otros, De Esteban, J., López Guerra, L., El régimen constitucional español, ob. cit., p. 18; Rodríguez Ramos, L., «Inviolabilidad del Rey», ob. cit., p. 286; Bastida Freijedo, F., «La Corona y la República», ob. cit., pp. 372-373. Rechazan esta posibilidad, GARcía CANALEs, M., La monarquía parlamentaria española, ob. cit., pp. 200-203; MENÉndez ReXACH, A., La Jefatura del Estado en el Derecho Público español, Madrid: INAP, 1979, p. 378; Torres del Moral, A., Principios de Derecho constitucional español, ob. cit., p. 513; Fernández-Fontecha Torres, M., Pérez de Armiñán y de la Serna, A., La monarquía y la Constitución, ob. cit., pp. 233-237; SOlOzÁBAl ECHEVARRíA, J.J., La sanción y la promulgación de la ley en la monarquía parlamentaria, Madrid: Tecnos, 1987, p. 116; Navas CASTillo, A., «Las competencias no legislativas de las Cortes Generales en relación con la Corona», en Torres Del Moral, A. (Dir.), Monarquía y Constitución, ob. cit., p. 545; Pascual Medrano, A., «La regencia», Torres del Moral, A. (Dir.), Monarquía y Constitución, ob. cit., pp. 250-254; González-Trevijano, P., «Artículo 56», ob. cit., p. 990. Por su parte, Santamaría Pastor, J. A., «Inhabilitación, Regencia y tutela del Rey», AAVV, La Monarquía parlamentaria, ob. cit., p. 411 aunque lo critica, entiende que los constituyentes utilizaron el término inhabilitación «en su más rancia significación civilista». Asimismo, Aragón Reyes, M., Dos estudios sobre la Monarquía parlamentaria en la Constitución española, ob. cit., pp. 76-77 parece admitir la inhabilitación por motivos políticos, aunque posteriormente la descarta en p. 117.

74 Así, Oliver Araujo, J., «La reforma constitucional de la Corona (una propuesta radical y diez moderadas)», ob. cit., pp. 53-55.

75 Resolución 92/XII, de 11 de octubre de 2018, sobre la «priorización de la agenda social y la recuperación de la convivencia» (BOPC, n. ${ }^{\circ} 177$, de 18 de octubre de 2018). 
rechazaba y condenaba el posicionamiento del Rey su intervención en el conflicto catalán y su justificación de la violencia ejercida por los policías en octubre de 2017; y se reafirmaba el compromiso con los valores republicanos y la apuesta por la abolición de la Monarquía. Dicha resolución fue declarada inconstitucional por la STC 98/2019, de 17 de julio $^{76}$, al entender el Alto Tribunal que la reprobación, en tanto emisión de un «juicio de contradicción u oposición» hacia el Monarca y su conducta, supone la imputación de una responsabilidad política y la atribución de una sanción del mismo tipo a aquél, proscrita ex art. 56.3 CE.

Dejando al margen la controvertida cuestión sobre si dicha resolución era susceptible de recurso ex arts. 161.2 CE y 76 y 77 LOTC — pues no parece que la misma tenga capacidad, siquiera indiciariamente, para producir efectos jurídicos, dado que no hay un llamamiento a las instituciones autonómicas para hacer algo, requisito imprescindible a la luz de la jurisprudencia constitucional para poder impugnar jurisdiccionalmente tales resoluciones autonómicas ${ }^{77}$ — en lo que aquí interesa, no parece constitucionalmente adecuada la interpretación que al respecto se hace de la inviolabilidad regia. Debe tenerse necesariamente en cuenta que de dicha resolución no se deriva, para el Monarca, ninguna consecuencia jurídica ni tampoco política (sustitución, inhabilitación, etc.), pues agota sus efectos en su propia exteriorización. Aquélla fue aprobada unos días después de la celebración de un debate general sobre la acción política y de gobierno en el seno del Parlamento catalán, al amparo de los arts. 154 y 155 de su Reglamento. Este tipo de «propuestas de resolución»-que en este caso adopta la forma de una moción - tienen una doble naturaleza, pues no tienen únicamente por fin activar la función de impulso político y control gubernamental —donde se incardinaría, en su caso, la responsabilidad política stricto sensu - sino promover la deliberación y la toma de posición de la Cámara respecto a un asunto determinado, operando así como un vehículo de expresión de opiniones o juicios sobre asuntos de interés para los representados y constituyendo, en ese sentido, una manifestación relevante del ius in officium de los parlamentarios (art. 23.2 CE $)^{78}$.

No se trata tanto, como subrayó en su dictamen el Consejo de Estado, de una declaración emitida a resultas de una actuación de control parlamentario como de una resolución conclusiva de un debate de política general que recoge un juicio valorativo sobre la actuación del Jefe del Estado en relación con determinados

76 Se han estimado posteriormente dos incidentes de ejecución de sentencia: AATC 184/2019, de 18 de diciembre y 11/2020, de 28 de enero. Asimismo, los AATC 33/2020, de 25 de febrero y 55/2020, de 17 de junio deniegan, respectivamente, los recursos de súplica interpuestos contra los anteriores Autos.

77 SSTC 42/2014, de 25 de marzo (FJ 2. ${ }^{\circ}$ ), 259/2015, de 2 de diciembre (FJ 2. ${ }^{\circ}$ ). En este sentido se manifestaba justamente el Dictamen el Consejo de Estado 892/2018, de 25 de octubre de 2018.

78 Desde las más tempranas SSTC 40/2003, de 27 de febrero (FJ 3. ${ }^{\circ}$ ); 78/2006, de 13 de marzo (FJ $3 .^{\circ}$ ); hasta las más recientes SSTC 212/2016, de 15 de diciembre (FJ 3. ${ }^{\circ}$ ); 11/2017, de 30 de enero (FJ 3. ${ }^{\circ}$ ); $124 / 2018$, de 14 de noviembre (FJ 7. ${ }^{\circ}$ ); entre otras. 
sucesos acontecidos en Cataluña. Así, no es que — como sostiene el Alto Tribunal- el Parlamento de Cataluña esté ejerciendo potestades de censura o reprobación de los actos regios de las que constitucionalmente carece, sino que sencillamente está debatiendo, aunque lo haga en sentido crítico, sobre la figura del Rey y su actuación, algo que no parece que en modo alguno caiga fuera de las atribuciones de un Parlamento autonómico, pues dicha sede es precisamente el lugar por excelencia donde dicha discusión debiera tener cabida, máxime cuando estamos en un sistema de democracia procedimental y no militante que no impone, en cuanto tal, límites materiales al debate público.

Esta jurisprudencia abría la puerta, sin demasiada dificultad, a que posteriores actos parlamentarios de contenido crítico o reprobatorio hacia el Monarca fueran inadmitidos a trámite por las Mesas parlamentarias al resultar contrarios a la Constitución ex art. 56.3 $\mathrm{CE}^{79}$. Eso fue justamente lo que sucedió en la XIV Legislatura con la inadmisión a trámite en términos absolutos de diversas solicitudes de creación de Comisiones de Investigación (fundamentalmente relativas la trama vinculada a las presuntas ilegalidades cometidas por miembros de la Casa Real y las influencias políticas, diplomáticas y comerciales con Arabia Saudí) ${ }^{80}$ y, especialmente, con la Resolución del Parlamento de Cataluña 298/XII, de 7 de marzo de 2019, de Creación de la Comisión de Investigación sobre la Monarquía $^{81}$. Ésta fue declarada inconstitucional por la STC 111/2019, de 2 de octubre al entender —en lo que aquí interesa — que la misma resultaba incompatible con la inviolabilidad del Monarca (Felipe VI) y de quién lo fuera (Juan Carlos) cuando acontecieron los hechos que se trataban de investigar, al implicar la atribución de una responsabilidad política a éstos. Este extremo, por cierto, confirma —a pesar de la opinión que aquí se sostiene- que el Tribunal Constitucional implícitamente entiende que la inviolabilidad blinda perpetuamente los actos del reinado aun tras la abdicación.

Aun cuando la Comisión de Investigación sobre la Monarquía pudiera resultar discutible por haberse creado, en este caso, en el ámbito autonómico — dado que el objeto de aquéllas debe ser de competencia de la Generalitat, ex arts.59.6 EAC y 67.1 RPC — desde luego no lo sería si aquélla fuera de ámbito nacional pues pueden crearse para investigar «cualquier asunto de interés público» (art. 76 CE) y la Jefatura del Estado sin duda lo es. Lo que no resulta tan comprensible $-\mathrm{y}$ es lo que aquí interesa - es que su inconstitucionalidad se haga también derivar

79 Así lo pronosticaba CaStillo López, F., «Nulidad de la resolución del Parlamento de Cataluña que desconoce la configuración constitucional de la Corona. Comentario a la sentencia del Tribunal Constitucional 98/2019, de 17 de julio. Impugnación de disposiciones autonómicas n. ${ }^{\circ}$ 5813-2018 (BOE n. ${ }^{\circ}$ 192, de 12 de agosto de 2019)», Revista de las Cortes Generales, n. ${ }^{\circ} 107,2019$, p. 489.

80 Pueden consultarse en el siguiente enlace: http://www.congreso.es/portal/page/portal/Congreso/ Congreso/Iniciativas?_piref73_2148295_73_1335437_1335437.next_page $=/$ wc/servidorCGI\&CMD $=$ VERLST $\& B A S E=I W 14 \& F M T=I N I T X L U S . f m t \& D O C O R D E R=F I F O \& O P D E F=Y \& Q U E R Y=\% 28 I \% 29$. ACIN1.+\%26+\%28CASA+REAL\%29.ALL.\&DOCS=26-50 (consultado el 15/12/2020)

81 BOPC n. ${ }^{\circ} 282$, de 11 de marzo de 2019. 
de su incompatibilidad con la inviolabilidad del Rey (art. 56.3 CE) $)^{82}$. Dichas comisiones constituyen una herramienta al servicio de la información de la Cámara que busca sacar a la luz y discutir informaciones de relevancia pública a las cuales no cabe anudar responsabilidad jurídica alguna (art. $76 \mathrm{CE}$, art. $53 \mathrm{RC}$, art. 60 RS) ni tampoco política stricto sensu, en los términos anteriormente mencionados.

Así las cosas, la jurisprudencia constitucional sobre la inviolabilidad del art. 56.3 CE ha contribuido a dotar de una notable vis expansiva a dicha prerrogativa. Y es que, si la activación de los instrumentos anteriormente mencionados no supone la atribución de ninguna responsabilidad jurídica ni tampoco política stricto sensu a aquél, constituyendo tan solo formas de vehicular el debate parlamentario entorno al Monarca y su actuación y, aún si, se reputan contrarias al art. 56.3 CE, es porque se está entendiendo que la inviolabilidad regia protege al Monarca también frente a la mera crítica o desaprobación, en este caso parlamentaria $^{83}$, es decir, frente a lo que podría considerarse la responsabilidad política difusa $^{84}$. No en vano el propio Tribunal entiende que aquélla le blinda nada menos que frente a «toda censura o control de sus actos» ${ }^{85}$.

Esto explica, al menos en parte, que la Mesa del Congreso haya inadmitido a trámite -impidiendo en este sentido la mera posibilidad de debatir al respecto- la Proposición de ley para el fomento de la transparencia económico-presupuestaria del Rey y de la Casa Real, presentada el 17 de julio de 2018, al entender que contradecía de forma palmaria y evidente los arts.56.3 CE y 65.1 $\mathrm{CE}$, inadmisión recurrida ante el Tribunal Constitucional y finalmente desestimada por la STC 24/2020, de 23 de febrero por cuestiones meramente formales. Sin embargo, dicha proposición de ley no pretendía interferir en los gastos del Rey ni de la Familia Real, ni coartar su capacidad de disposición sobre los mismos ni atribuirle ningún tipo de responsabilidad por la gestión efectuada al respecto, sino únicamente hacer accesible a la ciudadanía tales datos. Por los mismos motivos, en fin, ha sido también inadmitida a trámite muy recientemente la Proposición de Ley relativa al Registro Patrimonial de la Familia Real, presentada el 11 de noviembre de $2020^{86}$. Mientras esto sucede en España, en Luxemburgo, por

82 En este sentido, Pascua Mateo, F. A., «Nuevos (y necesarios) límites a las comisiones de investigación: competencias autonómicas y la inviolabilidad del Rey. Comentario a la sentencia del Tribunal Constitucional 111/2019, de 2 de octubre (BOE n. ${ }^{\circ}$ 262, de 31 de octubre de 2019)», Revista de las Cortes Generales, n. ${ }^{\circ}$ 108, 2020, p. 438 señala que las cuestiones competenciales hubieran ya bastado para declarar la inconstitucionalidad de la solicitud de creación de la Comisión de Investigación, sin tener que examinar su compatibilidad con el art. 56.3 CE

83 Así lo entendía, entre nosotros, por ejemplo, Rodríguez de MiÑón, M., «Artículo 56», ob. cit., p. 75. En esta línea también parecen situarse, en el ámbito comparado, FusiLier, R., Les Monarchies parlamentaires, Paris: Les Éditions Ouvrières, 1960, p. 392; DelpéréE, F., «La responsabilité du chef de l’État. Brèves observations comparatives», ob. cit., p. 35.

84 En los clásicos términos de Rescigno, U., La responsabilitá política, Milán: Giuffré, 1967, pp. 122 y ss.

85 SSTC 98/2019, de 17 de julio (FJ 3. ${ }^{\circ} \mathrm{c}$ ); 111/2019, de 2 de octubre (FJ 5. ${ }^{\circ} \mathrm{b}$ )

86 Téngase en cuenta, a este respecto, que la Ley 19/2013, de 9 de diciembre, de transparencia, acceso a la información pública y buen gobierno solo resulta aplicable a La Casal Real en lo referente a las actividades sujetas a Derecho administrativo (art. 2.1.f) 
ejemplo se ha elaborado el llamado «Informe Waringo» ${ }^{87}$ sobre el funcionamiento de la Casa Real que, entre otras cosas, analiza críticamente las cuestiones económicas y presupuestarias de la Familia Real, sin que tal cosa se haya considerado incompatible de forma alguna con la inviolabilidad regia.

$\mathrm{Y}$ es que la prerrogativa en cuestión libera al Jefe del Estado de todo tipo de responsabilidades, jurídicas y políticas, pero no debiera eximirle, frontalmente, de toda censura o control de sus actos, puesto que hay actuaciones de esta naturaleza que no implican la exigencia de las antedichas responsabilidades y que son, a su vez, ejercicios legítimos bien de una potestad o competencia, bien de un derecho fundamental en el sistema democrático ${ }^{88}$. Salvo que se entienda, como parece hacerlo el Tribunal, que cualquier tipo de crítica o manifestación de descontento, al suponer la atribución difusa de responsabilidades, debe considerarse constitucionalmente proscrita, interpretación expansiva de la que, tratándose de una prerrogativa, debe necesariamente huirse.

Tal cosa no encuentra, además, acomodo constitucional posible. Por un lado, resulta consustancial al sistema democrático la posibilidad de criticar y manifestar el descontento, especialmente en sede parlamentaria, sobre cualesquiera de los poderes públicos, inclusive el Jefe del Estado pues aquélla, como el propio Tribunal ha subrayado, es justamente ese «escenario privilegiado del debate público (...) en clave de libertad y pluralidad ${ }^{89}$. Así, no parece posible aislar la responsabilidad política difusa del Rey sin desnaturalizar el sistema democrático donde él mismo se incardina ${ }^{90}$. Por otro, las pretensiones del art. 56.3 CE no parece que consistan en silenciar las reprobaciones hacia el Monarca sino, como se ha visto, asegurar su función de ser símbolo de la unidad y permanencia del Estado, algo que no está reñido, como se viene sostenido, con soportar críticas hacia su persona o actuación, inherentes, por otra parte, al propio pluralismo político y social. El hecho de que el Jefe del Estado ocupe una posición supra partes y resulte ajeno a toda controversia política no significa que a los representantes políticos o a la propia ciudadanía deba resultarles ajena su actuación. De lo contrario, el aforismo de «the King cannot do wrong» ${ }^{91}$ acabaría por transformarse en una suerte de «the King cannot be said to do wrong».

87 Rapport du représentant spécial du Premier ministre auprès de la Cour grand-ducale, 2020, disponible aquí: https:/gouvernement.lu/fr/publications/rapport-etude-analyse/me/rapport-du-representant-special-du-premier-ministre-aupres-de-la-cour-grand-ducale.html (consultado el 15/12/2020).

88 En un sentido similar, ya tempranamente Aparicio, M.A., Introducción al sistema político y constitucional español, Barcelona: Ariel, 1994, p. 113; García CANALES, M., La monarquía parlamentaria española, ob. cit., p. 198.

89 SSTC 226/2004, de 29 de noviembre (FJ 6..$^{\circ}$ ), 227/2004, de 29 de noviembre (FJ 6. ${ }^{\circ}$ ); 39/2008, de 10 de marzo (FJ 7.'.).

90 Díez-PiCAzo, L.M., La criminalidad de los gobernantes, Barcelona: Crítica, 1996, p. 70 sostiene que la responsabilidad política difusa es consustancial al sistema democrático porque lo es, en suma, la posibilidad de criticar cómo se gestionan los asuntos públicos (aun cuando no se trate de cargos electivos).

91 Sobre el origen, evolución y significado de este aforismo, véase Pollock, F., Maitland, F. W., The History of English Law, vol. I, Cambridge: Cambridge University Press, 1968, pp. 511 y ss. 
Así las cosas, esta comprensión expansiva de la prerrogativa por parte de la jurisprudencia constitucional no se inserta dentro de la funcionalidad que justifica su existencia y funcionamiento sino que la desborda notablemente. Así, no es que la utilización de dichos mecanismos parlamentarios suponga una interferencia de las Cortes en la institución de la Corona sino a la inversa, una injerencia de la Monarquía —en base a una comprensión distorsionada de su estatuto jurídico- en las labores propias del Parlamento. De sostenerse dicha interpretación, hasta el propio intento por impulsar una reforma constitucional en clave republicana podría consistir en una censura política incompatible con la inviolabilidad del Rey o una forma de atribuirle responsabilidades por una desafortunada gestión de sus asuntos, algo que es un contrasentido pues no solo no existen límites materiales a la reforma constitucional, sino que están legitimados para impulsarla los propios Parlamentos autonómicos (art. 166.1 CE).

Es más, fuera de la arena estrictamente parlamentaria y, por tanto, del ámbito de las potestades/competencias, no resultaría descabellado que dicha interpretación sirviese para prohibir otras manifestaciones de descontento sobre el Jefe del Estado exteriorizadas por la propia sociedad a través, ahora, del ejercicio de distintos derechos fundamentales como el de expresión, reunión, manifestación, etc. Podría seguirse aduciendo que constituyen la imputación de una responsabilidad política difusa a aquél incompatible con el art. $56 \mathrm{CE}$ que le exonera de todo tipo de censura o control de sus actos. Sin embargo, lo cierto es que sucede y debe suceder al revés: que la crítica hacia los personajes públicos - y el Jefe del Estado lo es- debe estar especialmente protegida ${ }^{92}$.

En efecto, el TEDH, en el Asunto Otegi Mondragón c. España, de 15 de marzo de 2011, ha subrayado específicamente que «el hecho de que el Rey ocupe una posición de neutralidad en el debate político, una posición de árbitro y símbolo de la unidad del Estado, no podría ponerlo al abrigo de toda crítica en el ejercicio de sus funciones oficiales o — como en el caso- como representante del Estado que simboliza, en particular para los que rechazan legítimamente las estructuras constitucionales de este Estado, incluido su régimen monárquico». Añade, además, que «el hecho de que el Rey 'no esté sujeto a responsabilidad' en virtud de la Constitución española, en particular, a nivel penal, no podría suponer un obstáculo en sí al libre debate sobre su posible responsabilidad institucional, o incluso simbólica, a la cabeza del Estado, dentro de los límites del respeto a su reputación como a la de cualquiera» $(\text { c. } 55)^{93}$.

92 Véanse, entre muchas otras, las SSTEDH Lingens c. Austria, de 8 de julio de $1986(\$ 42)$; Oberschlick c. Autriche (no 2), de 1 de julio de 1997 (\$29); Pakdemirli c. Turquía, de 22 de mayo de 2005 (\$ 45); Stern Taulats et Roura Capellera c. España (\$32), de 13 de junio de 2018, entre otras. Sobre esta última, aunque recogiendo también la jurisprudencia anterior en la materia, puede verse el trabajo de Presno LinerA, M.A., "Crónica de una condena anunciada: el asunto Stern Taulats et Roura Capellera c. España sobre la quema de fotos del Rey», Teoría y Realidad Constitucional, n. ${ }^{\circ} 42,2018$, pp. 539 y ss.

93 La protección privilegiada de los jefes de Estado frente al ejercicio de los derechos a la libertad de expresión e información ya fue declarada incompatible con el CEDH en otras ocasiones. Véanse, las SSTEDH 
Así las cosas, en la medida en que la inviolabilidad del Rey, merced a una generosa interpretación de su alcance, pasa a desarrollar funciones que exceden las de la mera protección de aquéllas que tiene atribuidas, en cuanto tal, el titular de la Corona, va perdiendo indefectiblemente su justificación democrática. Al hacerlo, aquélla deja de ser ese elemento que, como se expuso en las primeras páginas, se insertaba dentro de la autorreferencialidad sistémica, beneficiando al funcionamiento conjunto del ordenamiento, contribuyendo, por el contrario, a diluirla en la medida en que se pone al servicio de intereses o pretensiones no reconducibles a los que tutela el ordenamiento democrático español. Por tanto, el problema no es la inviolabilidad del Rey, justificada existiendo una Monarquía, sino el alcance, material y temporal de que se dote a aquélla. La vis expansiva puede trasmutar, en suma, una justificable prerrogativa en un intolerable privilegio.

\section{$* * *$}

\section{TITLE: Meaning and Scope of the King's Inviolability}

AвSTRACT: The aim of this paper is to analyze both the role that the royal prerogative plays in the Spanish democratic system and its particular legal regime. For that purpose, it will be detached from past or bistorical conceptions which before justified its existence, trying to find its present foundation in the framework of a democratic Constitution, which will determine the function it is called to play in the Spanish legal order. Then, the paper will explore its legal scope, both in substantive and temporal terms, so as to verify whether it is compatible with the function the inviolability holds and, consequently, if we are dealing with a justifiable prerogative or an intolerable privilege.

RESUMEN: El objeto del presente artículo es analizar el papel que la inviolabilidad regia desempeña en el marco del sistema democrático español y su particular régimen jurídico. Para ello, aquélla tratará de desvincularse de concepciones pretéritas que justificaban su existencia, tratando de hallarle su fundamento en el marco de una Constitución democrática, desentrañando, a partir de la misma, la función que dicho instituto ostenta en el ordenamiento español. A continuación, tratará de estudiarse su alcance, tanto en términos temporales como materiales, a efectos de comprobar si resulta compatible o no con la función que la inviolabilidad tiene asignada; todo ello a efectos de determinar si nos hallamos ante una justificable prerrogativa o ante un intolerable privilegio.

KEY WORDs: King's inviolability, royal prerogative, prerogative, privilege, Monarchy, Crown.

Palabras Clave: inviolabilidad del Rey, Monarquía, prerrogativa, privilegio, Corona.

FECHA RECEPCIÓN: 16.12.2020 FECHA DE ACEPTACIÓN: 26.01.2021

asunto Colombani c. Francia, de 25 de junio de 2002; asunto Artun y Güvener c. Turquía, de 26 de junio de 2007; asunto Gutiérrez Suárez c. España, de 1 de junio de 2010; asunto Eon c. Francia, de 14 de marzo de 2013; asunto Couderc Et Hachette Filipacchi Associés c. Francia, de 12 de junio de 2014. 
